\title{
Conodonts with preserved soft tissue from a new Ordovician Konservat-Lagerstätte
}

\author{
RICHARD J. ALDRIDGE \\ Department of Geology \\ University of Leicester \\ Leicester, LE1 $7 R H$, \\ U.K.
}

\author{
JOHANNES N. THERON \\ Geological Survey \\ P.O. Box 752 \\ Bellville 7535, \\ South Africa
}

\begin{abstract}
A newly-discovered Konservat-Lagerstätte in the Upper Ordovician of South Africa has yielded giant conodont apparatuses, some of which are associated with preserved soft tissues of the conodont animals. Lobate structures located to the anterior of the conodont apparatus in several specimens are interpreted as sclerotic cartilages surrounding the eyes, comparing closely with those of the Silurian agnathan Jamoytius. One specimen also displays a possible trunk trace. J. Micropalaeontol., 12 (1): 113 117, August 1993.
\end{abstract}

\section{INTRODUCTION}

Conodonts remain a controversial group despite the discovery of more-or-less complete fossil specimens in the Carboniferous Granton shrimp bed of Edinburgh, Scotland (Briggs et al., 1983; Aldridge et al., 1986, in press). Features of the soft tissues are consistent with an agnathan affinity (Aldridge et al., 1986, in press; Conway Morris, 1989; Briggs, 1992), and new work on the histology of the apatitic conodont elements has revealed several vertebrate characteristics, including the presence of cellular bone tissue (Sansom et al., 1992). Although some specialists in early vertebrates have recently affirmed their uncertainties regarding conodont affinities (Blieck \& Janvier, 1991; Elliott et al., 1991; Blieck, 1992), and it has been argued that conodonts should be retained in a separate phylum (Sweet, 1988), the evidence that conodonts were vertebrates is now compelling. The interpretation of several features displayed by the Scottish soft-bodied animals is, however, still equivocal (Aldridge $e t$ al., in press), and a single specimen with poorly preserved soft tissue recovered from the Silurian of Wisconsin (Smith et al., 1987) has an apparently different body plan, adding to the uncertainties. This report documents the discovery of a third locality with preserved conodont soft tissue, in the Upper Ordovician Soom Shale of South Africa. The specimens display lobate soft-tissue features that are directly comparable with those from the Scottish Carboniferous, even though the conodont apparatuses themselves are significantly different.

\section{STRATIGRAPHICAL AND ENVIRONMENTAL SETTING}

The Soom Shale Member of the Cedarberg Formation forms a conspicuous marker horizon throughout the southwestern Cape Province amidst the predominantly arenitic units of the Table Mountain Group (Theron \& Thamm, 1990). It overlies the glaciogenic Pakhuis Formation, with a $50 \mathrm{~cm}$ layer of partly-bedded reworked glacial sediment constituting the contact at the best exposure, on the farm Keurbos, near Clanwilliam (see Theron et al., 1990). The Cedarberg Formation represents the outwash silt and mud from ice sheets retreating during the late Ordovician climatic amelioration, and the finely laminated sediments of the Soom Shale were deposited in a shallow, still-water marine environment, perhaps an embayment protected by partial ice-damming. The shale is, therefore, possibly unique among deposits preserving non-mineralized tissue in being situated in a high-latitude, glacially influenced environment.

\section{THE CONODONTS}

Exceptionally large conodont elements and complete giant (up to $20 \mathrm{~mm}$ ) apparatuses of the prioniodontid species Promissum pulchrum Kovács-Endrödy have been described from the basal Soom Shale Member at a single locality on Keurbos (Theron et al., 1990). The initial recognition of three complete conodont apparatuses has led to an intensive search for additional specimens at the same locality, where approximately 30 apparatuses, several partial apparatuses and isolated elements, and a number of other wellpreserved fossils have now been recovered. All the apparatuses belong to Promissum pulchrum and no other conodont species have been found in the Soom Shale either on bedding surfaces or by laboratory disaggregation of bulk rock samples.

Traces of conodont soft tissue are associated with at least five of the newly-discovered apparatuses. Most frequently preserved is a pair of lobate structures, represented by dark 


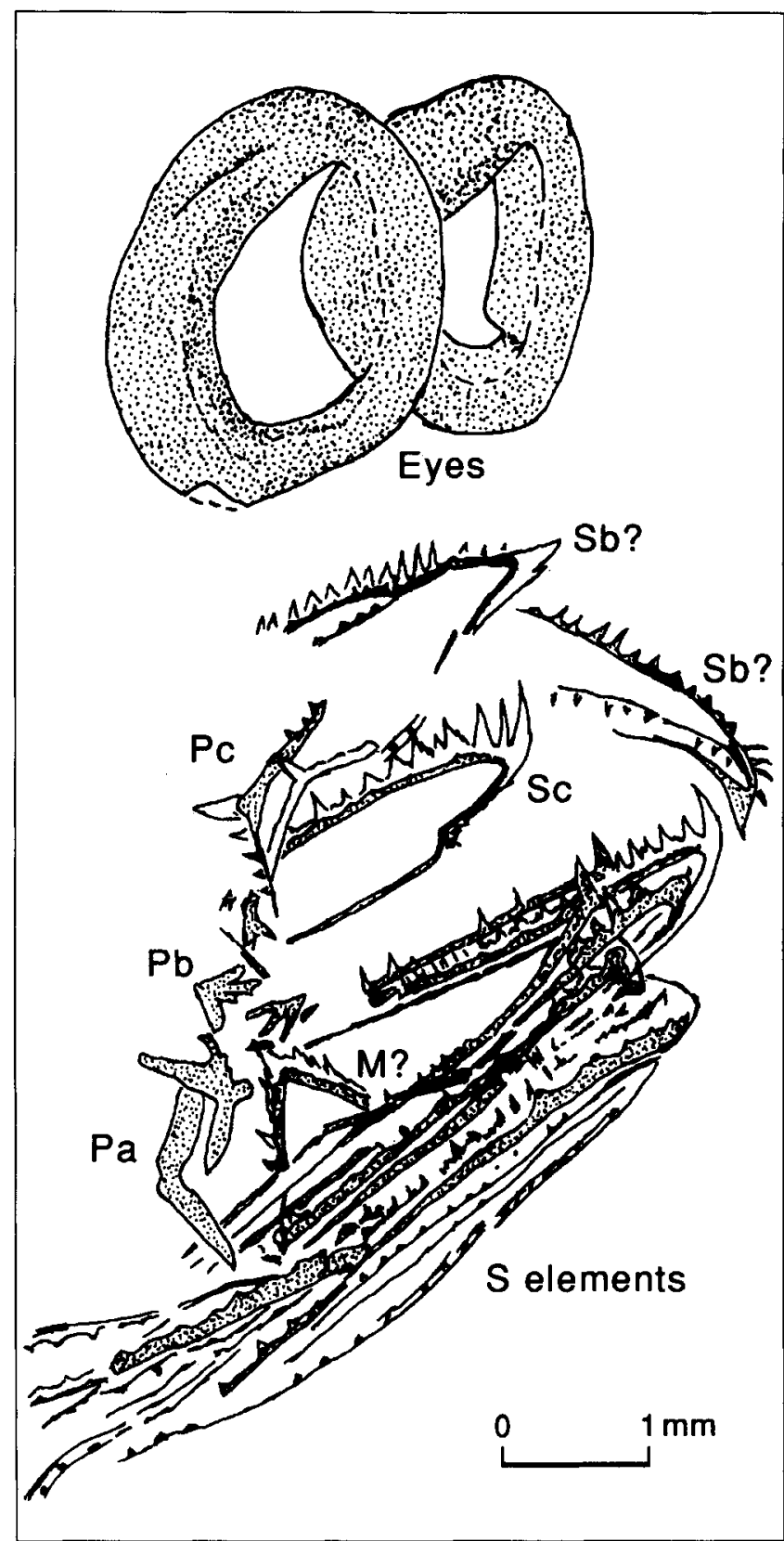

Fig. 1. Interpretative drawing of specimen C351a showing eyes and element positions; anterior to top. See also Pl. 1, fig. 2.

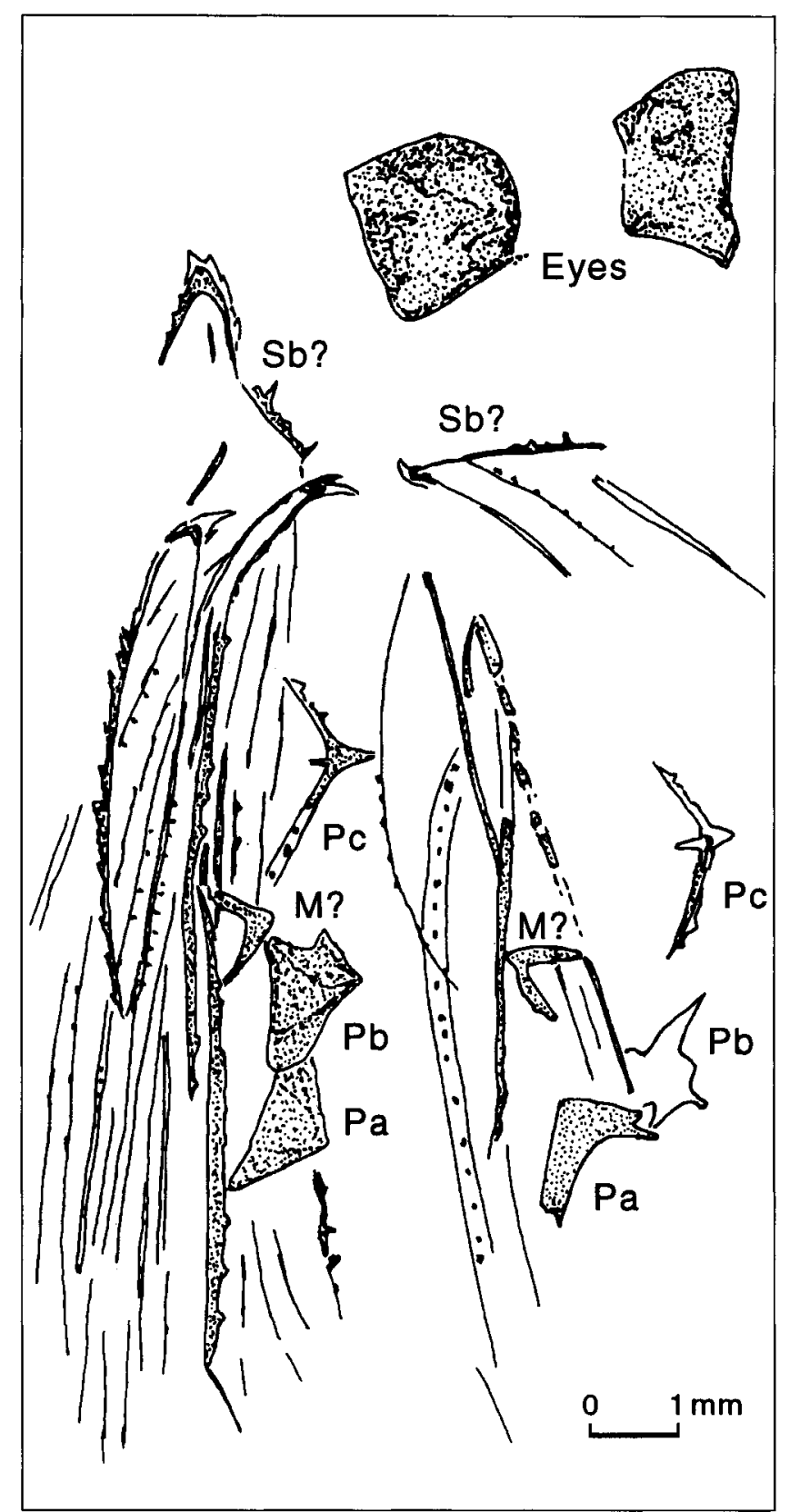

Fig. 2. Interpretative drawing of specimen C358a showing eyes and element positions; anterior to top. See also Pl. 1, fig. 3.

\section{Explanation of Plate 1}

Repository of specimens: Geological Survey of South Africa, Pretoria.

Fig. 1. Promissum pulchrum Kovács-Endrödy, specimen $\mathrm{C} 279 \mathrm{a}, \mathrm{x} 8$, anterior to top. Eyes apparent as two faint overlapping lobes at top of figure; length of lobes approximately $2.8 \mathrm{~mm}$. Apparatus in oblique lateral compaction (standard orientation) to the posterior of the eyes. Fig. 2. Promissum pulchrum Kovács-Endrödy, specimen C351a, $\times 9$, anterior to top. Eyes apparent as two strongly-preserved overlapping rings at top of figure; longer lobe $3.1 \mathrm{~mm}$. Apparatus in oblique lateral compaction (standard orientation) to the posterior of the eyes.

Fig. 3. Promissum pulchrum Kovács-Endrödy, specimen C358a, x6.5, anterior to top. Eyes apparent as two distinct trapezium-shaped structures at top right of figure; left-hand one $2.1 \mathrm{~mm}$ in length. Apparatus in dorso-ventral compaction.

Fig. 4. Promissum pulchrum Kovács-Endrödy, specimen C288a, x4, anterior to top. Eyes apparent as two coalesced lobes at top of figure, $2.3 \mathrm{~mm}$ in length. The pale grey, linear feature behined the eyes is a possible trunk trace. S elements of apparatus directed perpendicular to this trace in opposing half-apparatuses, posterior to the eyes and to their right. Two rows of P elements apparent immediately to the right of the anterior ramiform elements and midway between the eyes and the top right-hand corner of the figure. 

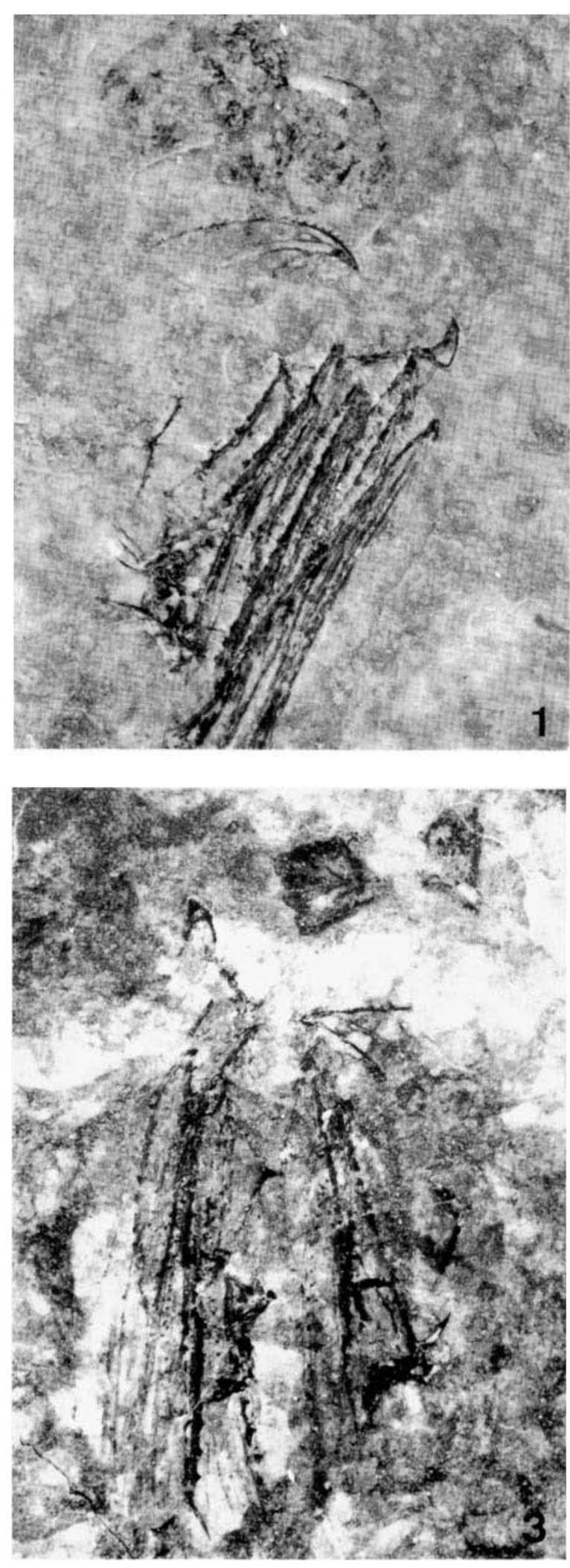
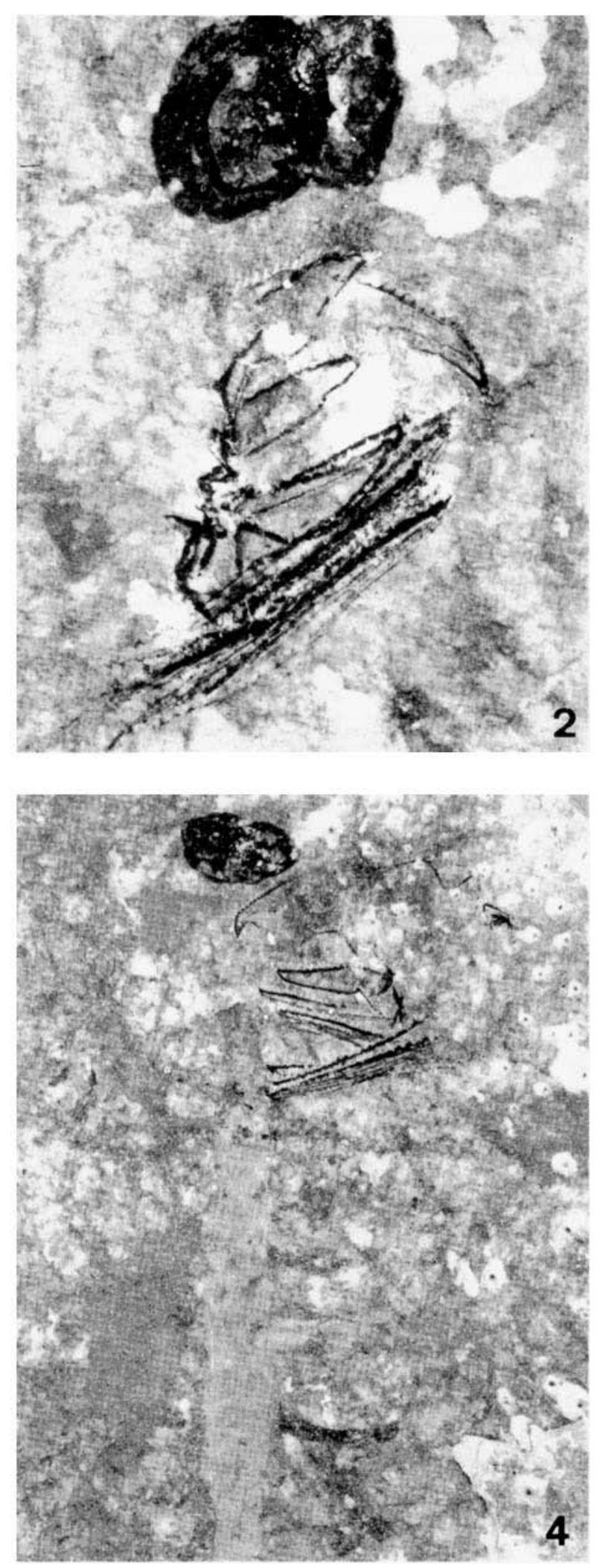
films and situated to the anterior of the feeding apparatus. On specimens with the apparatus in standard orientation (sensu Aldridge et al., 1987), indicating approximately lateral compaction, the two lobes partially overlap. The lobes on two specimens (C279, C351: Pl. 1, figs 1, 2; Fig. 1) show prominently preserved margins and an apparently hollow or unpreserved central area. One specimen (C358: Pl. 1, fig. 3; Fig. 2) is compacted in close to dorso-ventral orientation, with the opposing halves of the conodont apparatus facing each other across the axis of bilateral symmetry. The two lobes on this specimen are discrete; each has a straight outer margin and is trapezium-shaped with gently curved anterior, posterior and, possibly, inner margins. The axis between the pair of lobes is offset from that of the ramiform $S$ elements of the apparatus, suggesting that the compaction was a little oblique to dorso-ventral and that the lobes were situated above or below the line of the ramiforms in life. The axis between the rows of $\mathrm{P}$ elements is nearly confluent with that between the lobes, suggesting that each row was situated in line behind the respective lobe.

The lobate structures on Promissum compare closely with those recognised on the two most completely preserved ozarkodinid conodont animals from the Carboniferous Granton Shrimp Bed, Edinburgh. In the first Granton specimen (Briggs et al., 1983, fig. 3), the shape and orientation of the lobes are very similar to those of the dorso-ventrally compacted specimen of Promissum (C358: Fig. 2; Pl. 1, fig. 3). In specimen 5 of Aldridge et al.. (in press) from Granton, the lobes overlap in the same way as on other Promissum specimens and show the same strong preservation of the marginal zone. The lobes on the Granton specimens are smaller $(1.3 \mathrm{~mm}$ in length as against $2.1-3.1$ $\mathrm{mm}$ for the Soom Shale specimens), but clearly represent the same structures. They are unlikely to have formed a hood protecting the conodont apparatus, as the $S$ elements on the South African specimens are more than $2.5 x$ longer than the lobes.

The interpretation of the lobes on the first Granton specimen was left open, except for a statement that they possibly flanked a lumen leading to a mouth (Briggs et al., 1983). The South African specimens indicate that they represent paired structures of relatively high preservation potential. Possibilities include a cavity enclosing the semicircular canals, otic (auditory) capsules, or eyes. Extant myxinoids possess a single pair of semicircular canals, which are doughnut-shaped. However, these are not sclerotized and are situated posterior of the feeding apparatus (McVean, 1991). The large size and the shape of the structures in the conodont animals suggest that they are not otic capsules, but might be consistent with eyes. Dark stains representing eyes are common in fossil fish, and structures comparable with those found in the conodonts have been interpreted as representing the eyes in the Silurian anaspid Jamoytius. In Jamoytius, these annular features may be the remains of sclerotic cartilages surrounding the actual eyeball (Ritchie, 1968), and this would seem to be a reasonable interpretation of the conodont features. Their preservation as solid trapeziumshaped blocks in dorso-ventral compaction and as hollow subcircular structures in lateral compaction suggests that in three dimensions they were originally shaped as broad rings, expanding outwards.

On a single specimen from the Soom Shale, a linear grey trace extends behind the conodont apparatus (C288; P1. 1, fig. 4). This may represent the trunk of the animal, although no other features can be confidently discerned within it or associated with it. If projected forwards, the line of this trace intersects the anterior lobes with the apparatus offset to one side. The position of the trace, if it does indeed represent the trunk, is counter-intuitive, as it would suggest that the $\mathrm{P}$ elements were further from the axis than the $\mathrm{S}$ elements, with their denticulate surfaces directed away from the midline of the animal. More specimens are necessary to resolve this paradox.

The exposure of the Soom Shale at Keurbos is deeply weathered, and despite mechanical excavation fresh rock has yet to be reached. There is good potential for finding more complete soft-tissue preservation of conodonts and of other fossils. Already, a eurypterid with preserved appendages and muscle fibres has been recovered. Other fossils include inarticulate brachiopods, naraoiid trilobites, an orthocone cephalopod, a scolecodont apparatus, enigmatic spines and possible soft-bodied animals. Konservat-Lagerstätten are rare in the Ordovician (Allison \& Briggs, 1991), and, as well as promising new evidence of conodont anatomy, the Soom Shale will be important in filling a gap in the record of preserved soft-bodied organisms.

\section{ACKNOWLEDGEMENTS}

We thank Dr. C. S. MacRae and other palaeontologists of the Geological Survey of South Africa for field and laboratory assistance; Mr. A. Swift for help with photography; Drs D. E. G. Briggs and M. P. Smith for constructive comments; the Natural Environment Research Council, U. K, for Research Grant GR9/178 to RJA.

\section{Manuscript received October 1992}

Manuscript accepted February 1993

\section{REFERENCES}

Aldridge, R. J., Briggs, D. E. G., Clarkson, E. N. K. \& Smith, M. P. 1986. The affinities of conodonts - new evidence from the Carboniferous of Edinburgh, Scotland. Lethaia, Oslo, 19, 279 291.

Aldridge, R. J., Briggs, D. E. G., Smith, M. P., Clarkson, E. N. K. \& Clark, N. D. L. in press. The anatomy of conodonts. Phil. Trans. R. Soc. Lond. B

Aldridge, R. J., Smith, M. P., Norby, R. D. \& Briggs, D. E. G. 1987. The architecture and function of Carboniferous polygnathacean conodont apparatuses. In Aldridge, R. J. (Ed.), Palaeobiology of conodonts, 63-75. Ellis Horwood Ltd., Chichester for British Micropalaeontological Society. 
Allison, P. A. \& Briggs, D. E. G. 1991. Taphonomy of nonmineralized tissues. In: Allison, P. A. \& Briggs, D. E. G. (eds) Taphonomy: releasing the data locked in the fossil record, 2570. Plenum Press, New York \& London.

Blieck, A. 1992. At the origin of chordates. Geobios, Lyon, 25, 101-113.

Blieck, A. \& Janvier, P. 1991. Silurian Vertebrates. In Bassett, M. G., Lane, P. D. \& Edwards, D. (Eds), The Murchison Symposium: proceedings of an international conference on the Silurian System. Spec. Pap. Palaeontol., London, 345-389.

Briggs, D. E. G. 1992. Conodonts: a major extinct group added to the vertebrates. Science, Washington, 1285-1286.

Briggs, D. E. G., Clarkson, E. N. K. \& Aldridge, R. J. 1983. The conodont animal. Lethaia, Oslo, 16, 1-14.

Conway Morris, S. 1989. Conodont palaeobiology: recent progress and unsolved problems. Terra Nova, 1, 135-150.

Elliott, D. K., Blieck, A. R. M. \& Gagnier, P.-Y. 1991. Ordovician vertebrates. In Barnes, C. R. and Williams, S. H. (Eds), Advances in Ordovician Geology. Pap. geol. Surv. Can., 90-9, 93106.

McVean, A. 1991. The semicircular canals of the hagfish Myxine glutinosa. J. Zool., Lond., 224, 213-222.

Ritchie, A. 1968. New evidence on Jamoytius kerwoodi White, an important ostracoderm from the Silurian of Lanarkshire, Scotland. Palaeontology, London, 11, 21-39, pls 3-6.

Sansom, I. J., Smith, M. P., Armstrong, H. A. and Smith, M. M. 1992. Presence of the earliest vertebrate hard tissues in conodonts. Science, Washington, 256, 1308-1311.

Smith, M. P., Briggs, D. E. G. \& Aldridge, R. J. 1987. A conodont animal from the lower Silurian of Wisconsin, USA, and the apparatus architecture of panderodontid conodonts. In Aldridge, R. J. (Ed.), Palaeobiology of conodonts, 91-104. Ellis Horwood Ltd., Chichester for British Micropalaeontological Society.

Sweet, W. C. 1988. The Conodonts: morphology, taxonomy, paleoecology, and evolutionary history of a long-extinct animal phylum. Clarendon Press, Oxford, $x+212 \mathrm{pp}$.

Theron, J. N., Rickards, R. B. \& Aldridge, R. J. 1990. Bedding plane assemblages of Promissum pulchrum, a new giant Ashgill conodont from the Table Mountain Group, South Africa. Palaeontology, London, 33, 577-594, 4 pls.

Theron, J. N. \& Thamm, A. G. 1990. Stratigraphy and sedimentology of the Cape Supergroup in the Western Cape. Guidebook Geocongress ' 90 Geological Society of South Africa, PR2, 1-64. 